http://dx.doi.org/10.4314/jae.v17i1.5

\title{
Agricultural extension needs of farmers in Telfairia production and marketing in Enugu State, Nigeria
}

\author{
Abugu R. O, *Chah, J.M. , Nwobodo, C, Asadu A. N. and Igbokwe E.M. \\ Department of Agricultural Extension, University of Nigeria Nsukka \\ E-mail:jmchah@yahoo.co.uk \\ Phone: +2348032420600
}

\begin{abstract}
The study assessed agricultural extension needs of farmers in Telfairia production and marketing in Enugu State, Nigeria. Multistage sampling technique was used to select 160 Telfairia farmers for the study. Structured interview schedule was used to collect data. Data was analysed by use of descriptive statistics and factor analysis. Results show that farmers sold their products directly to consumers through village or local markets (56.9\%), village squares (27.6\%), at roadside stands (16.2\%), while $11.2 \%$ sold them at farm gate. Only $3.6 \%$ sold their products through cooperative societies. The quantity and price of sale of produce varied depending on the season of the year (26.6\%) in which the crop was produced, number of buyers $(20.0 \%)$ and quality of produce (16.2\%). About $63 \%$ of the respondents did not have extension contact in the last one year. Extension needs of farmers were indicated in the following areas: sourcing of farm input $(M=3.62)$, sourcing appropriate marketing channel ( $M=3.18)$, sourcing of improved farm tools $(M=3.11)$, expansion of scale of production $(M=3.07)$, receiving information on appropriate cultural practices $(M=$ 3.06), and sourcing farm credit ( $M=3.00)$. Infrastructural, technical, logistic and financial challenges hindered effective production and marketing of Telfairia among farmers. There is need for extension to assist farmers to source farm inputs and establish or explore viable markets where farmers will sell their products at a favourable price.
\end{abstract}

\section{Introduction}

Vegetables are among the major dietary intake in our everyday life. Vegetables usually augment nutritive value of most of our staple food which are deficient in vitamin, protein and minerals (Nwalieji, 2006). To provide adequate quantities of protein rich food, a family has to be fairly well to do. Therefore, our dietary needs could, to some appreciable extent, be met from the consumption of meals centred on vegetables, fresh grains and fruits (Muanya, 2003).

Apart from their nutritive value, vegetables are also good source of income to farmers who produce them. It is possible to earn much money annually on vegetable farming with a little start-up capital as against most arable crops (Eleke 2004). An annual income of about 3 million naira can be realized from vegetable

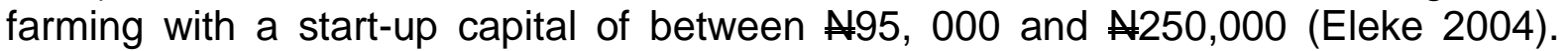
According to Ugwu (2001) it is an important cash crop known for steady supply of income. This could be through the sales of either the vegetative parts or the pods. 
Telfairia (fluted pumpkin) has become one of the popularly consumed vegetables as well as a lucrative farming business in Nigeria especially in Southeastern states. However, Telfairia production and consumption has gained popularity in many other parts of Nigeria because of its medicinal, economic and nutritive value (Ugwu, 2001). The crop forms one of the major components of human diet in many parts of Nigeria and may rank next to soya bean if properly processed (Achinewhu, 1990). It also has the ability to ratoon easily which shows that it can yield some amount of money to the farmers at off seasons when the newly planted ones are not well established. Medicinally, the leaves and juice are recommendable for pregnant women, lactating mothers and for the prevention of anaemia (Umeha, 2002). It also helps to solve gynecological, problems in both men and women.

Food and Agricultural Organization FAO (2002) notes that non-wood crops are essentially part of the local subsistence economies but has not received the required attention in the development plan and nutrition programmes of the population groups that depend on them. As a result of this, potential contribution of such crops to human welfare remains unrealized. Over the years, Telfairia is usually produced at a subsistence level and marketed locally, considering the perishable nature of the crop. This is attributable to some poor production and marketing strategies. The result is bulk production during on season and selling in local markets without any standardized measure or price and sometimes selling on credit. This also results to unemployment during off farm period. Marketing plays a critical role in meeting the overall goals of food security, poverty alleviation and sustainable agriculture, particularly among smallholder farmers in developing countries like Nigeria (Altshul, 1998; Lyster, 1990).

Provision of technical advice on important issues involving efficient production and marketing of Telfairia, will reposition farmers to address the challenges of production and efficient marketing of the crop. Agricultural extension plays vital roles in providing relevant technical services to the farmers. Provision of such relevant services requires proper assessment of the needs of the farmers. This study was therefore conducted to identify personal characteristics of the Telfairia farmers in the state; assess extension needs of the producers, ascertain marketing channels used by farmers and to identify constraints of Telfairia production and marketing in the state.

\section{Methodology}

The study was conducted in Enugu State, Nigeria. The state is made up of six (6) agricultural zones. All Telfairia farmers in the state constituted the population for the study. Multi-stage sampling technique was used to select respondents for the study. In the first stage, two (2) agricultural zones namely: Nsukka and Enugu Ezike were purposefully selected based on the dominance of Telfairia production. In the second stage, two (2) blocks out of 8 blocks from each of the zones were randomly selected using simple random sampling technique giving a total of four (4) blocks. In the third stage two (2) cells were randomly selected giving a total of 8 cells. Twenty farmers were randomly selected from a list of Telfairia farmers in the zone, giving a total sample size of one hundred and sixty (160) respondents used for the study. Data were collected using structured interview schedule. 
To assess the extension needs of farmers, a list of 11 possible needs was presented to the respondents. Their responses were evaluated on a $4-$ point Likert-type scale of highly needed $=4$, Needed $=3$, somehow needed $=2$, and not needed $=1$ was used. The values were added $(4+3+2+1)$ to get 10 which was divided by 4 to get a mean score of 2.5. Variables with mean score of 2.5 and above were regarded as areas of extension needs of farmers while variables which scored less than 2.5 were areas they had no extension needs. Data was analysis by use of descriptive statistics and factor analysis.

\section{Results and Discussions}

Majority $(58.1 \%)$ of the respondents were female (Table 1) showing that women were more involved in Telfairia production than men in the area. Sixty three percent of the respondents were part-time farmers while $55.6 \%$ of the farmers were smallscale producers (cultivated less than 2 plots) which agrees with the finding of Ugwu (2001) who opined that few people within Enugu North Agricultural Zone produce Telfairia at a subsistence level not minding the value of the crop. Production at subsistence level may minimized profit of the farmers. 
Table 1

Distribution of respondents according to socio-economic characteristics

\begin{tabular}{|c|c|c|c|}
\hline \multirow{2}{*}{\multicolumn{4}{|c|}{$\begin{array}{l}\text { Socio-economic characteristics } \\
\text { Sex }\end{array}$}} \\
\hline & & & \\
\hline Male & 67 & 58.1 & \\
\hline Female & 93 & 41.9 & \\
\hline \multicolumn{4}{|l|}{ Age (years) } \\
\hline $10-19$ & 14 & 8.8 & \\
\hline $20-29$ & 61 & 38.1 & \\
\hline $30-39$ & 34 & 21.2 & 33.4 \\
\hline $40-49$ & 30 & 18.8 & \\
\hline $50-59$ & 21 & 13.1 & \\
\hline 60 and above & 00 & 00 & \\
\hline \multicolumn{4}{|l|}{ Level of education } \\
\hline Non formal education & 9 & 5.6 & \\
\hline FSLC & 56 & 35.0 & \\
\hline WASC/GCE & 62 & 38.8 & \\
\hline OND/NCE/HND/B.ED/Others higher & 33 & 20.6 & \\
\hline \multicolumn{4}{|l|}{ Household size } \\
\hline $1-9$ & 118 & 73.8 & 8 \\
\hline $10-19$ & 33 & 20.6 & \\
\hline $20-29$ & 9 & 5.6 & \\
\hline \multicolumn{4}{|l|}{ Telfairia farming as major occupation } \\
\hline No & 101 & 63.1 & \\
\hline Yes & 59 & 36.9 & \\
\hline \multicolumn{4}{|c|}{ Others occupations apart from Telfairia farming } \\
\hline Artisan & 54 & 33.6 & \\
\hline Civil service & 76 & 47.6 & \\
\hline Farming & 160 & 100 & \\
\hline Petty trading & 32 & 20.0 & \\
\hline Apprentice Applicant & 6 & 3.8 & \\
\hline Student & 34 & 21.2 & \\
\hline \multicolumn{4}{|l|}{ Scale of farming } \\
\hline Large scale (used above 2 plots) & 71 & 44.4 & \\
\hline Small scale (used less than two plots) & 89 & 55.6 & \\
\hline
\end{tabular}

\section{Extension contacts with Telfairia farmers}

About $63 \%$ of the respondents did not have extension contact in the last one year (Table 2). Poor extension contact will often result in poor access to relevant information on how to improve Telfairia production and marketing and this could be a discouraging factor for the farmers. All (100\%) the farmers that had extension contact indicated that the information they obtained from extension agents was useful. This agrees with Obibuaku (1983) who reported that extension has the function of disseminating useful information relating to agriculture. Therefore, regular extension visit is required for improve production and income of Telfairia farmers in the area. Majority $(57.7 \%)$ of the farmers who had extension contact received information from extension agent's every 5 - 9 months while $22.1 \%, 18.6 \%, 1.7 \%$ 


\section{Journal of Agricultural Extension}

Vol. 17 (1) June, 2013

ISSN 1119-944X

received information every 10 - 14 months; $1-4$ months and 15 months and above respectively. This indicates that farmers do not receive extension information regularly. The frequency of contact determines the level and rate of adoption in any extension programmes. Therefore, the impact extension is making in the Telfairia production in the study area is low.

About $82 \%$ of the respondents received information on how to get farm inputs while $71.0 \%, 54.2 \%, 47.4 \%, 27.1 \%, 15.3 \%, 3.4 \%$ received information on how to source farm credit, family health, appropriate marketing channel, home management, record keeping and post planting operations, respectively. This implies that extension still has a lot of work to do in the area of production and marketing of Telfairia.

Table 2

Distribution of respondents according to extension contact

\begin{tabular}{|c|c|c|c|}
\hline Variables & Frequency & $\begin{array}{l}\text { Percentage } \\
\text { (\%) }\end{array}$ & Mean M \\
\hline \multicolumn{4}{|l|}{ Extension contact $(n=160)$} \\
\hline Yes & 59 & 36.9 & \\
\hline - & 101 & 63.1 & \\
\hline \multicolumn{4}{|l|}{ Reception of useful information ( $n=59)$} \\
\hline Yes & 59 & 100 & \\
\hline No & - & - & \\
\hline \multicolumn{4}{|l|}{ Frequency of reception $(n=59)$} \\
\hline Once in every $1-4$ months & 11 & 18.6 & \\
\hline Once in every $5-9$ months & 34 & 57.7 & 7.3 \\
\hline Once in every $10-14$ months & 13 & 22.1 & \\
\hline Once in every 15 months and above & 1 & 1.7 & \\
\hline \multicolumn{4}{|c|}{ Specific areas farmers received extension services $(n=59)$} \\
\hline Home management practices & 9 & 15.3 & \\
\hline Family health & 16 & 27.1 & \\
\hline Planting and post planting techniques & 32 & 3.4 & \\
\hline Assistance to source farm credit & 42 & 71.0 & \\
\hline Sourcing farm input & 48 & 81.6 & \\
\hline Sourcing appropriate marketing channel & 28 & 47.4 & \\
\hline
\end{tabular}

\section{Marketing channels and marketing information}

Farmers sold their products to consumers via several channels including (Table 3) village or local markets $(56.9 \%)$, village squares $(27.6 \%)$, roadside stands or street selling (16.2\%), and farm gate (11.2\%). Only 3.6\% sold their products through cooperative societies. The findings show that majority of the farmers sold directly to consumers. Ugwu (2001) reported that most of the farmers market their products in sub-standard markets where they are sold at a give-away price. This reduces their incentive to participate in economic transactions and result in subsistence rather than market-oriented production systems. However, Hall (2002) opined that justification for establishing a direct farmer-to-consumer marketing outlet is based primarily on the producer's desire to increase the financial returns from farm production. This opportunity for increased returns stems from opportunities to reduce marketing costs attributed to intermediaries (middle- men) in the supply chain, an consumer desire to buy (and willingness to perhaps pay a premium for) riper, 
fresher, higher-quality fruits and vegetables. These two factors combined have often generated substantially higher net returns for producers.

Roadside stands are located next to a public road so that they can be exposure to drive-by traffic. Farmers can charge less to consumers at the roadside while enhancing their own income because they often eliminate or reduce conventional marketing costs of intermediary firms. With knowledge of the advantages and disadvantages of these marketing channel alternatives, producers can evaluate their marketing needs and assess the likelihood that direct marketing will satisfy those needs. Farmers should therefore be educated on the opportunities of these market channels so that they can take advantage over them and increase production of maximize profit.

Table 3

Percentage distribution of respondents according to marketing channel ( $\mathrm{n}=$ 160)

\begin{tabular}{lll}
\hline Variable & Frequency & Percentage \\
\hline Farm gate & 18 & 11.2 \\
Cooperatives & 6 & 3.6 \\
Roadside stands & 26 & 16.2 \\
Village/local markets & 91 & 56.9 \\
Village square & 44 & 27.6 \\
Nearby town & 16 & 10.0 \\
Distant market & 7 & 4.4 \\
\hline
\end{tabular}

\section{Marketing factors that determine sales}

The level and price of sale of individual producers varied depending on the season of the year $(26.6 \%)$ in which they produce the crop, number (volume of sales) of buyers $(20.0 \%)$ and quality of produce $(16.2 \%)$ as shown in Table 4 . Fresh, high quality produce is important to customers. Harvest timing and post-harvest handling are two important factors affecting the quality of the produce (Hall, 2002).

The volume that can be sold through a given channel has a large impact on profitability. The more perishable the crop, the more important it is to have a channel that can absorb the volume harvested as quickly as possible. LeRoux et al. (2009) noted that choosing the appropriate marketing channel requires consideration of many factors, including sales volume, risk, lifestyle preference and stress aversion, labor requirements, and channel-specific costs. The weights (or importance) assigned to each of these factors is unique to the individual or firm. Additionally, the nature of highly perishable crops, along with the risks and potential sales volumes of particular channels, requires combining different channels to maximize firm performance.

Season of the years is also an important factor that affects sales. At on seasons produce are in much qualities, whereby supply is higher than demand and this may affect the price. Farmers should be educated on how to process excess Telfairia to meet demand during the rest of the year. Irrigation schemes should be developed for farmers to enable produce all year round in other to maximize profit. 


\section{Table 4}

Distribution of the respondents on the factors that determine sales

\begin{tabular}{lll}
\hline Variable & Frequency & Percentage \\
\hline Season of the year & 41 & 25.6 \\
Quality of produce & 26 & 16.2 \\
No of buyers & 32 & 20 \\
Distance to the market & 14 & 8.8 \\
Quality of produce & 16 & 10 \\
Selling on credit or cash & 21 & 13.1 \\
No standardized price & 6 & 3.8 \\
Place of sale & 4 & 2.5 \\
\hline
\end{tabular}

\section{Areas of extension need}

Extension needs of farmers was indicated in the following areas as shown in Table 5: sourcing of farm input $(M=3.62)$; sourcing appropriate marketing channel $(M=$ 3.18); sourcing of improved farm tools $(M=3.11)$; expansion of scale of production $(\mathrm{M}=3.07)$; receiving information on appropriate cultural practices $(\mathrm{M}=3.06)$; and sourcing farm credit $(M=3.00)$. The farmers further identified other areas of extension need as home management practices $(M=2.9)$; information on seed processing $(M=2.89)$; record keeping and evaluation $(M=2.84)$; family care and health care services $(M=2.76)$.

In the absence of well-developed markets, farmers will tend to self-insure by engaging in off-farm employment. Although the extra income could be used as investment in Telfairia farming it could play an important role in enterprises choices and investments decisions which may not favour Telfairia production. However, farmers will grow large quantities of Telfairia only when they are assured that they can market them easily.

Availability of credit and the associated cost of credit are crucial in the success of the agricultural industry. Credit could be used to purchase inputs (planting material, fertilizer and expand scale of production), pay wages, among others. The availability of credit is expected to lead to increased Telfairia production and commercialization. There is need for extension to intervene in these areas of need identified by farmers as any growth in Telfairia production is likely to affect poverty in different ways in rural areas. According to Osie (nd), traditional agronomic practices, disease and pest and inadequate extension advice, among others play a major role in reduced agricultural yields. However agricultural extension programmes provide the muchneeded help to farmers in the form of practical field advice and improved technologies from research institutions and the universities. Khalil, (2007) opined that agricultural extension activities are considered to be one of the most important activities in achieving the comprehensive rural development by transferring technologies from research stations to the farmers. 


\section{Table 5}

ISSN 1119-944X

Mean distribution of respondents based on areas of extension need

\begin{tabular}{lll}
\hline Variable & Mean score (M) & Standard Deviation \\
\hline Sourcing of farm input & $3.62^{*}$ & 0.758 \\
Sourcing appropriate marketing channel & $3.18^{*}$ & 0.910 \\
Sourcing improved farm tools & $3.11^{*}$ & 1.072 \\
Expansion of scale of production & $3.07^{*}$ & 1.061 \\
Need information on planting and post & $3.06^{*}$ & 1.070 \\
planting techniques & & \\
Sourcing farm credit & $3.00^{*}$ & 1.075 \\
Home management practices & $2.90^{*}$ & 1.122 \\
Seed processing techniques & $2.89^{*}$ & 1.163 \\
Record keeping and evaluation & $2.84^{*}$ & 1.195 \\
Family and health care services & $2.76^{*}$ & 1.151 \\
\hline
\end{tabular}

${ }^{*}=$ Extension needs of farmers

\section{Factors constraining the production and marketing of Telfairia}

Constraint factors were extracted and variables with 0.4 and above were used in naming the factors (Table 4). Based on the clustering of items, factors 1, 2, 3, and 4 were named infrastructural, technical, logistic and financial constraints respectively. The major constraints under infrastructural limitations (factor 1 ) as identified by the farmers include poor technical know-how on the production (0.62); unsuitable time of transaction (0.50); poor infrastructural facilities (0.44); and poor access to irrigation facilities (0.41). Inadequate irrigation facilities and perishability of Telfairia limit producers to on-season production and sales at a low price owing to lack of storage facilities.

In factor 2, (technical problems) specific constraint variables were inadequate credit facilities (0.57); inadequate storage facilities (0.56); and lack of extension contact (0.44). Items that loaded high under logistic problems (factor 3 ) include unsuitable marketing channel (0.55); poor access to improved seeds (0.51); and unavailability of other farm input like fertilizer, agro chemicals (0.48) while items that load under financial problems (factor 4 ) include: inadequate fund (0.55) and family problems (e.g. sickness, children's' education (0.41).

Poor technical know-how on production is a significant constraint to vegetable production and the capacity of small producers in particular. According to (USAID, 2005), ineffective and inaccessible extension and education networks have resulted in inadequate human technical capacity and expertise throughout the horticultural (vegetable) market chain in developing countries. Extension should have effective mechanisms to ensure that farmers are trained in currently required methodologies and practices in the production of Telferia.

Compared to cereal crops, most vegetables demand high levels of inputs. Small holder farmers often lack access to appropriate inputs and the necessary technical production skills due to inadequate input and credit markets as well as weak extension systems (USAID, 2005). Improving access to appropriate inputs and 


\section{Journal of Agricultural Extension}

Vol. 17 (1) June, 2013

ISSN 1119-944X

information resources can help farmers raise productivity and contribute to sound natural resource management.

Unsuitable market channels may result in vegetables being wasted as postharvest losses. This often cause a reduction in the price of the vegetables and consequently the inability of the farmers to sustain their livelihood. Makhura (2001) found that marketing by smallholder farmers in switzerland was constrained by poor infrastructure, distance from the market, lack of assets (such as lack of own vehicles) and inadequate market information. Lack of bargaining power along with various credit bound relationships with the buyers have led to farmers being exploited during the transaction where most of the farmers become price takers and this may affect commercialization of this venture. Jaleta (2007) showed that inadequate market channels and poor information regarding price were among factors affecting commercialisation of agriculture. Furthermore, Emana and Gebremedhin (2007) in their study on market chain analysis argued that the marketing of horticultural crops is affected by inadequate local markets, poor pricing system, lack of local markets to absorb supply, low produce prices, excess of intermediaries, and poor marketing institutions and coordination of farmers. Emana and Gebremedhin (2007) further argued that poor handling and packaging of products, poor pricing systems, and information asymmetry affect marketing of vegetables.

Given the high local demand for vegetables, it is important to address these challenges for producers to benefit from market opportunities and to increase their incomes. Dealing with these challenges will require a whole value chain approach. 
Table 4

Varimax rotated factors constraining production and marketing of Telfairia

\begin{tabular}{|c|c|c|c|c|}
\hline Variables & $\begin{array}{l}\text { Factor } 1 \\
\text { (Infrastructur } \\
\text { al problems) }\end{array}$ & $\begin{array}{l}\text { Factor } 2 \\
\text { (technical } \\
\text { problems) }\end{array}$ & $\begin{array}{l}\text { Factor 3 } \\
\text { (Logistic } \\
\text { problem } \\
\text { s) }\end{array}$ & $\begin{array}{l}\text { Factor } 4 \\
\text { (Financial } \\
\text { problems } \\
\text { ) }\end{array}$ \\
\hline Inadequate fund & -0.17 & 0.11 & 0.23 & -0.55 \\
\hline Inadequate credit facilities & 0.06 & 0.57 & -0.22 & -0.22 \\
\hline Lack of extension contact & 0.01 & 0.44 & 0.05 & 0.18 \\
\hline $\begin{array}{l}\text { Lack of frequent extension } \\
\text { contact }\end{array}$ & -0.04 & -0.30 & 0.32 & 0.14 \\
\hline Family problem (sickness) & 0.16 & 0.01 & 0.06 & 0.41 \\
\hline High cost of labour & 0.20 & 0.37 & 0.04 & -0.05 \\
\hline Small sized farm land & -0.04 & 0.02 & -0.02 & 0.18 \\
\hline Poor access to improved seeds & 0.18 & -0.04 & 0.51 & -0.10 \\
\hline $\begin{array}{l}\text { Unavailability of other input } \\
\text { (fertilizer, agro chemicals etc.) }\end{array}$ & -0.00 & -0.03 & 0.48 & 0.04 \\
\hline High cost of input & 0.17 & 0.32 & -0.02 & 0.38 \\
\hline Weed problem & 0.29 & 0.12 & 0.05 & 0.06 \\
\hline Pest and disease problem & -0.39 & -0.55 & -0.05 & -0.01 \\
\hline $\begin{array}{l}\text { Poor access to irrigation } \\
\text { facilities }\end{array}$ & 0.41 & -0.01 & 0.25 & 0.02 \\
\hline Lack of irrigation facilities & -0.02 & 0.32 & 0.34 & -0.10 \\
\hline $\begin{array}{l}\text { Poor knowledge of soil related } \\
\text { factors }\end{array}$ & 0.51 & -0.07 & -0.40 & 0.16 \\
\hline Climate variation (drought) & -0.03 & 0.10 & -0.28 & -0.33 \\
\hline Poor infrastructural facilities & 0.44 & -0.02 & -0.21 & -0.36 \\
\hline Poor pricing system & 0.03 & 0.39 & -0.13 & 0.21 \\
\hline $\begin{array}{l}\text { Poor technical know-how on } \\
\text { producing }\end{array}$ & 0.62 & 0.01 & 0.11 & -0.11 \\
\hline Poor storage system & -0.17 & 0.38 & 0.01 & 0.33 \\
\hline Inadequate storage facilities & -0.00 & 0.56 & 0.09 & -0.06 \\
\hline Unsuitable marketing channel & 0.50 & 0.16 & 0.55 & 0.24 \\
\hline Inadequate transport facilities & -0.28 & 0.24 & 0.01 & -0.33 \\
\hline High cost of transportation & -0.52 & 0.03 & -0.36 & 0.30 \\
\hline Unsuitable time of transactions & -0.50 & 0.03 & 0.02 & -0.30 \\
\hline Instability of price & -0.07 & 0.05 & 0.09 & 0.24 \\
\hline
\end{tabular}

\section{Conclusion}

Agricultural extension need of Telfairia producers were identified in the following areas: sourcing farm credit, farm input, appropriate marketing channel, fertilizer application, pest disease and weed control. Farmers produce the crop at a small scale and sold in village markets. Infrastructural, 


\section{Journal of Agricultural Extension}

Vol. 17 (1) June, 2013

ISSN 1119-944X

technical, logistic and financial problems were identified as constraints in production and marketing of Telfairia. There is need for extension to establish or explore viable markets where farmers will sell their products at a favourable price in relation to the quantity and quality of the produce. Non-Governmental Organizations (NGO) should also help to provide inputs, infrastructures, logistics, marketing information and finance needed for effective production and marketing of the crop.

\section{References}

Achinewhu, S. C. and Isichei, M. O. (1990). The nutritional evaluation of fermented fluted pumpkin (Telfairia occidentalis Hook F.) Discovery and Innovation 2: 62 -65 .

Altshul, H. (1998). Output to purpose review of DFID's Crop Post-harvest Programme, Value Addition to Agricultural Products. Natural Resources International Symposium, 53-61.

Eleke, S.E.C. (2004). Vegetable for cash. Saturday Daily Independent Newspapers. October 30, pp. 88.

Emana, B., \& Gebremedhin, H. (2007). Constraints and Opportunities of Horticultural Production and Marketing in Eastern Ethiopia. Drylands Coordination Group Report No. 46.

Food and Agriculture Organization (2002). Non-word forest products and nutrition, Rome.

Hall, C. R. (2002). Direct marketing guide for producers of fruits, vegetable and other specialty products. Agricultural Extension Service The University of Tennessee Pp 40 available at http://www.utextension.utk.edu Accessed 28/04/2013.

Jaleta, M. (2007). Econometric analysis of horticultural production and marketing in central and eastern Ethiopia. Unpublished PhD Dissertation, Wageningen University. Wageningen, Netherlands

LeRoux, M.N Schmit, T.M. Roth, M.and Streeter D.H. (2009). Evaluating Marketing Channel Options for Small-Scale Fruit and Vegetable Producers: Case Study Evidence from Central New York. 14853-7801 April.

Lyster, D. M. (1990). Agricultural marketing in KwaZulu: a farm-household perspective. Unpublished MSc Agric thesis, University of Natal, Pietermaritzburg.

Makhura, T. (2001). Overcoming transaction costs barriers to market participation of smallholder farmers in the Northern Province of South Africa. Unpublished PhD dissertation University of Pretoria. June, 2001. 


\section{Journal of Agricultural Extension}

Vol. 17 (1) June, 2013

ISSN 1119-944X

Muanya, C. (2004). Pineapple as a panacea for yuletide ailment. Thursday Guardian, October 16, p. 61.

Nwalieji, H. U. (2006). Evaluation of Fadama phase one vegetable production project of the Anambra State agricultural development programme. M.Sc. thesis project submitted to the Department of Agricultural Extension, University of Nigeria, Nsukka

Obibuaku, L. O. (1983). Agricultural Extension as a strategy for Agricultural Transformation, Nsukka, University of Nigeria, Press.

Osei, C.K, (ND). Building the capacity of agricultural facilitators and farmers in Ghana: Providing complementary training with Open Distance Learning and Information and Communications Technology. Available at http://pcf4.dec.uwi.edu/viewpaper.php?id=134\&print=1. Accessed 29/04/13.

Sofela, I. (2001). Agriculture: Pineapple as a panacea for malnutrition. The Monitor Newspapers: B4.

Ugwu, F.J. (2001). Studies on the aetiology of the wilt disease of fluted pumpkin in Nsukka Local Government Area of Enugu State. M.Sc. thesis submitted to Department of Botany, University of Nigeria, Nsukka.

Umeha, C. (2002). The imperatives of nutrition for pregnant mothers and growing children. The Guardian Newspapers p. 30.

USAID (2005). Global horticultural assessment. The world vegetable center. June. Available http://pdf.usaid.gov/pdf docs/pnadh769.pdf. Accessed 26/12/12. 